\title{
WPEYW WYBRANYCH REGULACJI UE NA ROZWÓJ RYNKU MAGAZYNOWANIA GAZU ZIEMNEGO W POLSCE
}

\section{The impact of selected EU regulations on the development of natural gas storage market in Poland}

\author{
Aleksander ZAWISZA ${ }^{1,2}$ \\ ${ }^{1}$ Operator Gazociagów Przesytowych Gaz-System SA; \\ ul. Mszczonowska 4, 02-337 Warszawa; \\ e-mail: aleksander.zawisza@gaz-system.pl \\ ${ }^{2}$ Instytut Studiów Politycznych PAN (doktorant)
}

Treść: Zapisy przyjęte w dyrektywie o emisjach przemysłowych 2010/75/EU (IED) oraz rozporządzeniu Parlamentu Europejskiego i Rady (UE) nr 994/2010 skutkować będą na początku spadkiem, a następnie wzrostem popytu na pojemności magazynowe na zapasy obowiązkowe gazu ziemnego w Polsce. Jednocześnie normy, jakie powinny spełniać instalacje magazynowe, w których przechowywane będą te zapasy, faworyzują pod względem możliwości technicznego odbioru podziemne magazyny gazu ziemnego w kawernach solnych. Dodatkowym czynnikiem stymulującym popyt na pojemności magazynowe w strukturach solnych będzie rozwój rynku gazu ziemnego i powstanie giełdy gazu posiadającej istotne znaczenie dla tworzącego się rynku gazu ziemnego.

Słowa kluczowe: gaz ziemny, popyt, podaż, podziemne magazyny gazu, dyrektywy UE

\begin{abstract}
The provisions adopted in Directive 2010/75/EU on industrial emissions (IED) and Regulation of the European Parliament and of the Council (EU) No. 994/2010 will result first in a drop and then an increase of the demand for the natural-gas mandatory-reserve storage capacity in Poland. At the same time, the standards to be met by storage facilities that hold such stocks will favour in this respect underground storage of natural gas in salt caverns. An additional factor stimulating the demand for storage capacity in salt structures will include the development of the natural gas market and the establishment of gas exchange that will have a significant impact on the natural gas market.
\end{abstract}

Key words: natural gas, demand, supply, underground gas storages, EU directives 


\section{WPROWADZENIE}

Rozporzadzenie Parlamentu Europejskiego i Rady (UE) nr 994/2010 z dnia 20 października 2010 r. w sprawie środków zapewniających bezpieczeństwo dostaw gazu ziemnego i uchylenia dyrektywy Rady 2004/67/WE (Dziennik Urzędowy Unii Europejskiej L 295/1) określa warunki i ramy, w jakich powinny działać państwa i podmioty na rynku gazu ziemnego, aby zapewnić nieprzerwane dostawy tego nośnika energii. W rozporządzeniu tym znajduje się definicja „odbiorców chronionych”, czyli „wszystkich odbiorców będących gospodarstwami domowymi, którzy są już podłączeni do sieci dystrybucyjnej gazu”. Ponadto, o ile tak postanowi dane państwo członkowskie, „termin ten może obejmować również:

a) małe i średnie przedsiębiorstwa ${ }^{1}$, pod warunkiem, że są one podłączone do sieci dystrybucyjnej gazu, a także podmioty świadczące podstawowe usługi socjalne, pod warunkiem że są one podłączone do dystrybucyjnej lub przesyłowej sieci gazowej, a także pod warunkiem że na wszystkich tych dodatkowych odbiorców przypada najwyżej do $20 \%$ ostatecznego zużycia gazu; lub

b) instalacje systemów ciepłowniczych, o ile dostarczają energię cieplną odbiorcom prywatnym oraz odbiorcom, o których mowa w lit. a), pod warunkiem że instalacje te nie są w stanie przełączyć się na inne paliwa i są podłączone do sieci dystrybucji lub przesyłu gazu".

Państwa członkowskie miały czas do dnia 3 grudnia 2011 r., aby powiadomić Komisję Europejską, czy zamierzają uwzględnić podmioty wymienione w literze a) lub b) w swojej definicji odbiorców chronionych. Rząd Polski powiadomił KE, że do definicji odbiorców chronionych w przypadku Polski zostaną włączone podmioty wymienione w literze b). Podmioty wymienione w literze a) nie mogły być uwzględnione, gdyż zużycie gazu przez te podmioty przekracza w Polsce $20 \%$ zużycia całkowitego. Ponadto rozporządzenie w art. 8 ust. 1 stanowi, że „Właściwy organ zobowiązuje określone przez siebie przedsiębiorstwa gazowe do podjęcia środków w celu zapewnienia dostaw gazu odbiorcom chronionym $\mathrm{z}$ danego państwa członkowskiego w następujących przypadkach:

a) ekstremalnych temperatur w siedmiodniowym okresie szczytowego zapotrzebowania, występującym z prawdopodobieństwem statystycznym raz na 20 lat;

b) każdego przynajmniej trzydziestodniowego okresu nadzwyczajnie wysokiego zapotrzebowania na gaz, występującego z prawdopodobieństwem statystycznym raz na 20 lat; oraz

c) przynajmniej trzydziestodniowego okresu w przypadku wystąpienia zakłóceń w największej pojedynczej infrastrukturze gazowniczej w przeciętnych warunkach w okresie zimowym".

${ }^{1}$ Chodzi o definicje małych i średnich przedsiębiorstw według standardów UE, co oznacza, że za małe przedsiębiorstwo uznaje się podmiot, który zatrudnia poniżej 50 osób oraz spełnia co najmniej jeden z następujących warunków: roczny przychód nie przekracza $10 \mathrm{mln}$ euro lub/i suma bilansowa nie przekracza $10 \mathrm{mln}$ euro. Za średnie przedsiębiorstwo uznaje się podmiot, który zatrudnia powyżej 50, ale nie więcej niż 250 osób oraz spełnia co najmniej jeden z następujących warunków: roczny przychód nie przekracza $10 \mathrm{mln}$ euro lub/i suma bilansowa nie przekracza $10 \mathrm{mln}$ euro. 
Art. 8 ust. 2 rozporządzenia stanowi, że „Każdy podwyższony standard w zakresie dostaw przekraczający 30 dni dla okresów, o których mowa w ust. 1 lit. b) i c), lub każdy dodatkowy wymóg nałożony ze względu na bezpieczeństwo dostaw gazu opierają się na ocenie ryzyka, o której mowa w art. 9, znajdują odzwierciedlenie w planie działań zapobiegawczych”. $\mathrm{Z}$ kolei art. 9 ust. 1 omawianego rozporządzenia stanowi, że w terminie do dnia 3 grudnia 2011 r. każdy właściwy organ dokonuje pełnej oceny ryzyka związanego z bezpieczeństwem dostaw gazu w jego państwie członkowskim. Ocena ryzyka powinna się odbywać zgodnie $\mathrm{z}$ zasadą $\mathrm{N}-1^{2} \mathrm{z}$ uwzględnieniem szeregu warunków specyficznych dla danego rynku. Gdyby ocena ryzyka z zastosowaniem zasady $\mathrm{N}-1$ dała wynik niepozwalający na zaspokojenie popytu na gaz, państwo członkowskie mogłoby zastosować podwyższony standard w zakresie dostaw przekraczający 30 dni, o którym mowa w zacytowanym wyżej art. 8 ust. 2. Rząd polski w przedstawionej pod koniec $2011 \mathrm{r}$. KE analizie ryzyka stwierdził, że analiza N - 1 wypada w przypadku Polski pozytywnie, czyli wskaźnik N - 1 jest wyższy od 100\%. Było to o tyle zastanawiające, że kilka miesięcy wcześniej minister właściwy do spraw gospodarki wydał zarządzenie o uwolnieniu zapasów obowiązkowych, a najwięksi odbiorcy mieli ograniczone dostawy gazu ziemnego. Sytuacja taka oznaczała, że z jednej strony państwo polskie stwierdziło, że w przypadku wystąpienia sytuacji kryzysowej możliwe będzie pełne zaspokojenie zapotrzebowania odbiorców, ale z drugiej strony w okresie zimowym ograniczano dostawy do największych konsumentów. Gdyby analiza przedstawiona przez Ministerstwo Gospodarki wskazywała, że w przypadku wystąpienia kryzysu posiadana infrastruktura oraz warunki kontraktowe (kontrakt jamalski) jej wykorzystywania nie zapewnią zaspokojenia zapotrzebowania odbiorców na gaz, to w myśl zacytowanego powyżej art. 8 ust. 2 państwo polskie mogłoby zastosować podwyższony standard. Standard ten mógłby dotyczyć np. ilości zapasów obowiązkowych oraz szybkości ich oddawania do systemu przesyłowego.

Należy zwrócić uwagę na to, że rozporządzenie w art. 8 stanowi o zapewnieniu dostaw, a nie tworzeniu zapasów obowiązkowych. Tym samym każde państwo członkowskie ma możliwość w swoim prawodawstwie nakazania lub nienakazania tworzenia zapasów obowiązkowych. Ponadto nie ma jasności, czy tworzone na podstawie prawa polskiego zapasy obowiązkowe są ,rezerwami strategicznymi gazu”, o których mowa w załączniku III do rozporządzenia.

Zgodnie z wyżej przedstawioną argumentacją, w myśl omawianego rozporządzenia zapasy obowiązkowe gazu ziemnego zostaną w Polsce ograniczone do zapasów dla odbiorców chronionych. Wielkość tych zapasów, w zależności od ostatecznie przyjętych definicji w projektowanej ustawie Prawo gazowe, wynosiła będzie około $600 \mathrm{mln} \mathrm{m}^{3}$ gazu (Informacja przedstawiciela Ministerstwa Gospodarki 2013). Zapasy te, zgodnie z przepisami UE, muszą być gromadzone w instalacjach, których parametry techniczne zapewniają możliwość

\footnotetext{
${ }^{2}$ Wzór N - 1 opisuje zdolność techniczną infrastruktury gazowniczej do zaspokojenia całkowitego zapotrzebowania na gaz na obszarze analizowanym w przypadku zakłóceń w funkcjonowaniu pojedynczej największej infrastruktury gazowej w dniu nadzwyczajnie wysokiego zapotrzebowania, występującym statystycznie raz na 20 lat. Infrastruktura gazownicza obejmuje sieć przesyłową gazu, w tym połączenia wzajemne, jak również instalacje produkcyjne, LNG i magazynowe przyłączone do obszaru analizowanego.
} 
dostarczenia całkowitej ilości zapasów obowiązkowych do systemu gazowego krajowego w okresie nie dłuższym niż 30 dni (projekt ustawy Prawo energetyczne). Oznacza to, że zapasy obowiązkowe gazu ziemnego po wprowadzeniu tak zapisanej implementacji przepisów UE spadną o około $280 \mathrm{mln} \mathrm{m}^{3}$ (Informacja przedstawicieli PGNiG 2013). Niemniej szybkość udostępniania zapasów obowiązkowych gazu ziemnego, czyli oddawanie ich do systemu przesyłowego tych zapasów, praktycznie się nie zmieni, gdyż będzie ono wynosiło co najmniej $20 \mathrm{mln}^{3}$ na dobę, co oznacza, że większość zapasów obowiązkowych nadal będzie przechowywana w kawernach solnych.

W przyszłości wielkość zapasów obowiązkowych, w tym także zapasów przechowywanych w kawernach solnych, będzie wzrastała między innymi ze względu na:

- rozwój gazyfikacji kraju, a co się z tym wiąże - wzrost liczby odbiorców chronionych podłączanych do systemów dystrybucyjnych;

- wzrost znaczenia gazu w ciepłownictwie, w tym w ciepłownictwie sieciowym;

- rozwój rynku gazu i wprowadzanie nowych nie znanych jeszcze w Polsce usług związanych z handlem, przesyłem i magazynowaniem gazu ziemnego.

Problemem z budowaniem nowej infrastruktury magazynowej, której posiadanie z jednej strony zapewnia ciągłość dostaw, a z drugiej przyczynia się do rozwoju rynku gazu, jest brak długookresowych mechanizmów finansowania takich inwestycji, zwłaszcza jeżeli chodzi o tworzenie zapasów obowiązkowych gazu ziemnego. Zgodnie z obecnie obowiązującymi unijnymi regulacjami możliwe jest powstanie funduszu składkowego mającego na celu tworzenie i finansowanie obowiązkowych zapasów gazu ziemnego. Powołanie składkowego systemu tworzenia i utrzymywania zapasów obowiązkowych byłoby możliwe i zgodne z art. 3 ust. 6 Rozporzadzenia Parlamentu Europejskiego i Rady (UE) nr 994/2010 z dnia 20 października 2010 r. w sprawie środków zapewniajacych bezpieczeństwo dostaw gazu ziemnego i uchylenia dyrektywy Rady 2004/67/WE: „Środki na rzecz zapewnienia bezpieczeństwa dostaw zawarte w planach działań zapobiegawczych i planach na wypadek sytuacji nadzwyczajnej muszą być jasno określone, przejrzyste, proporcjonalne, pozbawione cech dyskryminacji i weryfikowalne, nie mogą w niewłaściwy sposób zakłócać konkurencji ani skutecznego funkcjonowania rynku wewnętrznego gazu i nie mogą zagrażać bezpieczeństwu dostaw gazu do innych państw członkowskich lub Unii jako całości”. Nadmienić należy, że nowelizacja ustawy o zapasach obowiązkowych, jaka jest obecnie (połowa 2013 r.) procedowana przez rząd, ma powołać fundusz składkowy w celu tworzenia i utrzymywania zapasów obowiązkowych ropy naftowej i paliw ciekłych.

\section{DYREKTYWA O EMISJACH PRZEMYSLOWYCH - IED}

W przypadku analiz dotyczących prawa o czystości powietrza (nie dotyczy to emisji $\mathrm{CO}_{2}$ ) mamy do czynienia obecnie między innymi z następującymi dokumentami ${ }^{3}$ :

\footnotetext{
${ }^{3}$ Nie licząc dokumentów, które jeszcze obowiązują, ale w ciągu trzech lat stracą swoją moc obowiązującą, czyli traktatu o przystąpieniu RP do UE, dyrektywy 2001/80/WE (LCP) i dyrektywy 2001/81/WE (NEC) oraz dyrektywy Parlamentu Europejskiego i Rady 2008/50/WE.
} 
Rozporzadzeniem Ministra Środowiska z 22 kwietnia 2011 r. w sprawie standardów emisyjnych z instalacji (Dz. U. nr 95, poz. 558) oraz Dyrektywa Parlamentu Europejskiego i Rady 2010/75/EU z dnia 24 listopada 2010 r. w sprawie emisji przemysłowych (zintegrowane zapobieganie zanieczyszczeniom i ich kontrola) (wersja przeksztatcona) (Dziennik Urzędowy Unii Europejskiej L 334/17). Ten ostatni dokument, zwany dyrektywą IED, dotyczy ograniczenia emisji przemysłowych $\mathrm{SO}_{2}, \mathrm{NO}_{\mathrm{x}}$ i pyłów, których normy emisji zostały w sposób znaczący zaostrzone.

W tabeli 1 zaprezentowano zmiany norm $\mathrm{SO}_{2}$ zawarte w różnych przepisach prawnych.

Tabela (Table) 1

Zmiany norm $\mathrm{SO}_{2}$ zawarte w przepisach prawnych (Kopczyński 2012)

Revisions of $\mathrm{SO}_{2}$ standards acted in legal regulations (Kopczyński 2012)

\begin{tabular}{|c|c|c|c|c|c|c|}
\hline \multirow{3}{*}{$\begin{array}{c}\text { Moc cieplna } \\
\text { w paliwie }\left[\mathrm{MW}_{\mathrm{t}}\right]\end{array}$} & \multicolumn{3}{|c|}{ Średnie stężenie $\mathrm{SO}_{2}\left[\mathrm{mg} / \mathrm{Nm}^{3}\right]$} & \multirow{2}{*}{\multicolumn{3}{|c|}{$\begin{array}{c}\text { Średnie stężenie emisji } \\
\mathrm{SO}_{2}\left[\mathrm{mg} / \mathrm{Nm}^{3}\right] \text { wynikające } \\
\text { z konieczności dotrzymania limitóy } \\
\text { emisji zapisanych w traktacie } \\
\text { o przystąpieniu RP do UE (2003 r.) }\end{array}$}} \\
\hline & $\begin{array}{c}\text { rozporządzenie } \\
\text { Ministra } \\
\text { Środowiska }\end{array}$ & $\begin{array}{l}\text { dyrektywa } \\
\text { LCP }\end{array}$ & \multirow{3}{*}{ 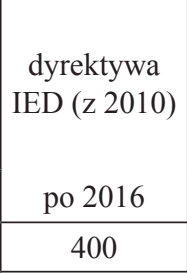 } & & & \\
\hline & \multicolumn{2}{|c|}{ lata $2008-2015$} & & 2008 & 2010 & 2012 \\
\hline$\langle 50 ; 225)$ & 1480 & 1720 & & 1390 & 1266 & 933 \\
\hline$\langle 225 ; 500)$ & 1210 & 1210 & 300 & 1091 & 956 & 642 \\
\hline$\langle 500 ; \ldots)$ & 400 & 400 & 200 & 367 & 331 & 320 \\
\hline
\end{tabular}

Normy zawarte w dyrektywie dotyczą kotłów o mocy powyżej $15 \mathrm{MW}_{\mathrm{t}}$. Na moc źródła składa się suma mocy kotłów podłączonych do jednego komina, co oznacza, że źródłem emisji nie jest tak jak obecnie kocioł, ale komin. Dodatkowo został wprowadzony wymóg monitorowania emisji całkowitej rtęci w źródłach opalanych węglem. Wejście w życie nowych norm emisji nastąpi 1 stycznia 2016 r. Jednakże w dyrektywie określono kilka okresów przejściowych i tak na przykład instalacje, które będą zamknięte przed 1.01.2023 i w latach 2016-2023 nie przepracują więcej niż 17500 godzin, nie będą musiały spełniać wymogów IED. W preferencyjny sposób potraktowano także ciepłownictwo sieciowe, czyli takie, które według dyrektywy co najmniej 50\% ciepła wytwarza na potrzeby publicznej sieci ciepłowniczej: instalacje o mocy do $200 \mathrm{MW}_{\mathrm{t}}$ nie będą musiały spełniać nowych norm do 31.12.2022 r.

Należy zatem zadać pytanie, jakie są możliwości spełnienia przez podmioty, których IED dotyczy, nowych norm? Trzy główne to: po pierwsze dokonanie odpowiednich inwestycji w instalacje odsiarczania, redukcji tlenków azotu i pyłów, po drugie dokonanie konwersji z opalania węglem na opalanie gazem, po trzecie odpowiednia kombinacja kotłów węglowych i gazowych. Pierwsza możliwość jest opłacalna pod względem ekonomicznym w przypadku instalacji powyżej 120 MW, chociaż należy zakładać, że będą występowały sytuacje, w których niektórzy inwestorzy i właściciele będą dokonywali zmiany paliwa także 
w większych jednostkach, np. ze względu na redukcje emisji $\mathrm{CO}_{2}$. Źródła o mniejszych mocach będą w większości dokonywały zamiany paliwa. W tabeli 2 zaprezentowano podział przedsiębiorstw na grupy według kryterium wielkości mocy.

Tabela (Table) 2

Klasyfikacja przedsiębiorstw ciepłowniczych według kryterium wielkości mocy (Energetyka... 2011)

Heating plants according to power groups (Energetyka ... 2011)

\begin{tabular}{|c|c|c|c|}
\hline Moc $[\mathrm{MW}]$ & $\begin{array}{c}\text { Liczba przedsiębiorstw } \\
\text { ciepłowniczych }\end{array}$ & $\begin{array}{c}\text { Łączna moc } \\
\text { zainstalowana }\left[\mathrm{MW}_{\mathrm{t}}\right]\end{array}$ & Moc osiągana [MW $\left.\mathrm{MW}_{\mathrm{t}}\right]$ \\
\hline $5-10$ & 57 & 347,6 & 333,0 \\
\hline $10-25$ & 91 & 1565,4 & 1623,9 \\
\hline $25-50$ & 101 & 3630,0 & 3413,0 \\
\hline $50-75$ & 43 & 2634,9 & 2675,4 \\
\hline $75-125$ & 49 & 4893,8 & 4732,8 \\
\hline
\end{tabular}

W zależności od przyjętych założeń potencjał wzrostu rynku gazu do 2022 r. (ostateczna data wejścia w życie przepisów dyrektywy IED można oszacować na 5-12 mld $\mathrm{m}^{3}$. Tabela 3 przedstawia scenariusze kształtowania się zapotrzebowania na pojemności magazynowe przeznaczone na przechowywanie zapasów obowiązkowych gazu ziemnego w zależności od wielkości konsumpcji oraz wskaźnika wykorzystywania ciepła przez odbiorców uznawanych w rozporządzeniu SoS i projektowane prawo polskie za odbiorców chronionych. W obliczeniach założono, że ilość zapasów obowiązkowych będzie proporcjonalna do ilości sprzedanego ciepła odbiorcom chronionym.

Tabela (Table) 3

Scenariusze zapotrzebowania na pojemności magazynowe

Storage capacity demand scenarios

\begin{tabular}{|c|c|c|c|c|c|}
\hline \multirow{2}{*}{$\begin{array}{c}\text { Potencjał wzrostu } \\
\text { rynku [mld m }\end{array}$} & \multicolumn{5}{|c|}{ Wskaźnik ciepła dostarczanego odbiorcom chronionym } \\
\cline { 2 - 6 } & $40 \%$ & $50 \%$ & $60 \%$ & $70 \%$ & $80 \%$ \\
\cline { 2 - 6 } & \multicolumn{5}{|c|}{ pojemność magazynowa [mln $\left.\mathrm{m}^{3}\right]$} \\
\hline 5 & 164,4 & 205,5 & 246,6 & 287,7 & 328,8 \\
\hline 6 & 197,3 & 246,6 & 295,9 & 345,2 & 394,5 \\
\hline 7 & 230,1 & 287,7 & 345,2 & 402,7 & 460,3 \\
\hline 8 & 263,0 & 328,8 & 394,5 & 460,3 & 526,0 \\
\hline 9 & 295,9 & 369,9 & 443,8 & 517,8 & 591,8 \\
\hline 10 & 328,8 & 411,0 & 493,2 & 575,3 & 657,5 \\
\hline 11 & 361,6 & 452,1 & 542,5 & 632,9 & 723,3 \\
\hline 12 & 394,5 & 493,2 & 591,8 & 690,4 & 789,0 \\
\hline
\end{tabular}


W tabeli 4 przestawiono obliczone na podstawie danych z tabeli 3 wielkości, o jakie powinno wzrosnąć, w porównaniu z sytuacją bazową oznaczającą wydajność $20 \mathrm{mln} \mathrm{m}^{3}$ na dobę, średniodzienne wydawanie gazu ziemnego będącego zapasem obowiązkowym z magazynów.

\section{Tabela (Table) 4}

Konieczny wzrost możliwości średniodziennego wydawania do systemu gazowego gazu ziemnego z magazynów gazu

The necessary increase in average daily donation of natural gas

\begin{tabular}{|c|c|c|c|c|c|}
\hline \multirow{2}{*}{$\begin{array}{c}\text { Potencjał wzrostu } \\
\text { rynku }\left[\mathrm{mld} \mathrm{m}^{3}\right]\end{array}$} & \multicolumn{5}{|c|}{ Wskaźnik ciepła dostarczanego odbiorcom chronionym } \\
\cline { 2 - 6 } & $40 \%$ & $50 \%$ & $60 \%$ & $70 \%$ & $80 \%$ \\
\hline 5 & 5,48 & 6,85 & 8,22 & 9,59 & 10,96 \\
\hline 6 & 6,58 & 8,22 & 9,86 & 11,51 & 13,15 \\
\hline 7 & 7,67 & 9,59 & 11,51 & 13,42 & 15,34 \\
\hline 8 & 8,77 & 10,96 & 13,15 & 15,34 & 17,53 \\
\hline 9 & 9,86 & 12,33 & 14,79 & 17,26 & 19,73 \\
\hline 10 & 10,96 & 13,70 & 16,44 & 19,18 & 21,92 \\
\hline 11 & 12,05 & 15,07 & 18,08 & 21,10 & 24,11 \\
\hline 12 & 13,15 & 16,44 & 19,73 & 23,01 & 26,30 \\
\hline
\end{tabular}

Mając na względzie realizowany obecnie przez Grupę Kapitałową Polskiego Górnictwa Naftowego i Gazownictwa SA program inwestycyjny polegający na rozbudowie istniejących i budowie nowych podziemnych magazynów gazu ziemnego (strategie GK PGNiG z 2008 i 2012 r.), a także przygotowywaną zmianę przepisów prawa (zapasy obowiązkowe tylko dla odbiorców chronionych), należy stwierdzić, że wolumeny z tabeli 3 nie są wielkościami, z których osiągnięciem może zaistnieć w ciągu najbliższych ośmiu lat szczególny problem. W skrajnym przypadku na zapasy obowiązkowe powinno być przeznaczone $1389 \mathrm{mln} \mathrm{m}^{3}$ $\left(600 \mathrm{mln} \mathrm{m}^{3}+789 \mathrm{mln}^{3}\right)$ pojemności magazynowych (nie uwzględnia się wzrostu konsumpcji związanego z gazyfikacją poza ciepłownictwem). Jednakże podążający za wzrostem ilości zapasów obowiązkowych wzrost tempa odbioru gazu ziemnego będącego zapasem obowiązkowym z magazynów zaprezentowany w tabeli 4 bez budowy nowych podziemnych wysokosprawnych magazynów na gaz ziemny będzie niemożliwy do osiągnięcia. Tym samym powstaje już dziś potrzeba rozpoczęcia inwestycji w nowe wysokosprawne podziemne magazyny w strukturach solnych, w taki sposób, aby w perspektywie kilku - kilkunastu lat móc przy wykorzystaniu gazu składowanego w rozmieszczonych na terenie Polski magazynach obsługiwać bez napięć rynek gazu ziemnego.

Dlatego też w ramach rozwoju rynku gazu, a także w trosce o zapewnienie bezpieczeństwa dostaw należy rozważyć możliwość przejęcia od przedsiębiorców przez państwo obowiązku tworzenia rezerw (zapasów) gazu ziemnego. Zapasy te byłyby tworzone 
od sprzedanego gazu ziemnego (nie jak ma to miejsce obecnie od jego importu) do odbiorców chronionych, właścicielem i dysponentem byłaby Agencja Rezerw Materiałowych. Zapasy byłyby tworzone i utrzymywane ze składek płaconych przez sprzedawców gazu ziemnego. Tworzenie zapasów od sprzedaży zapewniłoby równe traktowanie różnych podmiotów. Powstałby mechanizm sprzyjający długookresowemu inwestowaniu w wysokowydajne magazyny gazu, jakie są konieczne do przechowywania gazu ziemnego stanowiącego zapas obowiązkowy. Mogłoby być to zorganizowane na podobnej zasadzie, na jakiej od jesieni 2012 r. proponowana jest częściowa zmiana sytemu tworzenia i finansowania zapasów obowiązkowych ropy naftowej i paliw płynnych. W tabeli 5 zaprezentowano porównanie dwóch rynków, dla których w Polsce istnieją zapasy obowiązkowe.

Tabela (Table) 5

Porównanie rynku ropy naftowej i paliw ciekłych z rynkiem gazu ziemnego

Comparison of crude oil and liquid fuel markets with the natural gas market

\begin{tabular}{|c|c|c|c|}
\hline Lp. & Kryterium & $\begin{array}{l}\text { Rynek ropy naftowej i pa- } \\
\text { liw ciekłych }\end{array}$ & Rynek gazu ziemnego \\
\hline 1 & $\begin{array}{c}\text { Szacunkowa wartość } \\
\text { zapasów obowiązkowych } \\
\text { na } 31.12 .2012 \text { r. [mln zł] }\end{array}$ & $14000^{\mathrm{a}}$ & $1100^{\mathrm{b}}$ \\
\hline 2 & $\begin{array}{c}\text { Ilość zapasów obowiązko- } \\
\text { wych w dniach }\end{array}$ & $115^{\mathrm{c}} / 120^{\mathrm{d}}$ & $30^{\mathrm{e}}$ \\
\hline 3 & $\begin{array}{l}\text { Pojemność całkowite } \\
\text { magazynów w dniach } \\
\text { konsumpcji }\end{array}$ & $131^{\mathrm{f}}$ & 45 \\
\hline 4 & $\begin{array}{l}\text { Deficyt /nadwyżka }(-/+) \\
\text { podaży magazynów } \\
\text { w dniach śreniorocznej } \\
\text { konsumpcji }\end{array}$ & $+7^{\mathrm{g}}$ & $-45^{\mathrm{h}}$ \\
\hline 5 & $\begin{array}{l}\text { Tempo rozbudowy }{ }^{\mathrm{i}} \\
\text { budowy magazynu }\end{array}$ & 6-24 miesięcy / 3-5 lat & $3-5$ lat $/ 4-20$ lat \\
\hline 6 & $\begin{array}{c}\text { Podmiot regulujący stawki } \\
\text { za usługi magazynowania }\end{array}$ & Rynek & Prezes Urzędu Regulacji Energetyki \\
\hline 7 & $\begin{array}{l}\text { Liczba potencjalnych do- } \\
\text { stawców medium i moż- } \\
\text { liwości odbioru z innych } \\
\text { niż obecnie kierunków } \\
\text { i od innych dostawców }\end{array}$ & $\begin{array}{l}\text { W promieniu } 400 \mathrm{~km} \\
\text { od granic RP znajduje się } \\
11 \text { rafinerii o łącznej mocy } \\
\text { przerobowej } 58,5 \text { mln ton } \\
\text { ropy naftowej rocznie, } \\
\text { dodatkowo poprzez morskie } \\
\text { terminale przeładunkowe } \\
\text { można obecnie importować } \\
\text { około } 10 \text { mln ton paliw } \\
\text { rocznie (50\% rocznej kon- } \\
\text { sumpcji paliw w Polsce) }\end{array}$ & $\begin{array}{l}\text { Wyłączając gazociągi dostarczające } \\
\text { gaz ziemny od strony wschodniej, } \\
\text { dostawy możliwe są poprzez wirtu- } \\
\text { alny rewers na gazociągu jamalskim } \\
\left(2,5 \mathrm{mld}^{3}\right) \text {, gazociąg Morawia } \\
\left(0,5 \mathrm{mld} \mathrm{m}^{3}\right) \text {, gazociąg z punk- } \\
\text { tem rozliczeniowym w Lasowie } \\
\left(1,5 \mathrm{mld}^{3}\right) \text {; wielkość tych dostaw } \\
\text { stanowi około } 30 \% \text { całkowitej kon- } \\
\text { sumpcji gazu ziemnego; dostawy } \\
\text { morzem są obecnie niemożliwe }\end{array}$ \\
\hline
\end{tabular}


Tabela (Table) $5 \mathrm{~cd}$.

\begin{tabular}{|c|c|c|c|}
\hline 8 & $\begin{array}{l}\text { Sezonowość sprzedaży } \\
\text { paliwa - różnica pomię- } \\
\text { dzy miesiącem o najniż- } \\
\text { szej i najwyższej kon- } \\
\text { sumpcji }\end{array}$ & $20 \%$ & $150 \%$ \\
\hline 9 & $\begin{array}{c}\text { Liczba zdarzeń, jakie } \\
\text { można uznać za kryzy- } \\
\text { sowe w czasie ostatnich } \\
10 \text { lat }\end{array}$ & $\begin{array}{l}1 \text { (przerwa w dostawach } \\
\text { ropy naftowej ropociągiem } \\
\text { „Przyjaźń” w styczniu } \\
2007 \text { r. - czas trwania } 3 \text { dni) }\end{array}$ & $\begin{array}{c}3 \text { (przerwanie dostaw w lutym } \\
2004 \text { r. z gazociągów dostarczają- } \\
\text { cych gaz poprzez Białoruś - czas } \\
\text { trwania } 3 \text { dni, ograniczenie dostaw } \\
\text { na początku } 2006 \text { r. - czas trwania } \\
7 \text { dni, ograniczenie dostaw na po- } \\
\text { czątku } 2009 \text { r. - czas trwania } 19 \text { dni) }\end{array}$ \\
\hline 10 & $\begin{array}{l}\text { Środki transportu, jakimi } \\
\text { może być dostarczane } \\
\text { medium (w większości } \\
\text { przypadków) w Polsce }\end{array}$ & $\begin{array}{c}\text { Statek, rurociąg, kolej, } \\
\text { autocysterna }\end{array}$ & Rurociąg \\
\hline 11 & $\begin{array}{l}\text { Zakres podmiotów two- } \\
\text { rzących zapasy }\end{array}$ & $\begin{array}{l}\text { Wszyscy bez wyjątków } \\
\text { importerzy i producenci }\end{array}$ & $\begin{array}{l}\text { Każdy przedsiębiorca importujący } \\
\text { powyżej } 100 \mathrm{mln} \mathrm{m}^{3} \text { ( } 1 \% \text { ogółu } \\
\text { importu) gazu rocznie }\end{array}$ \\
\hline 12 & $\begin{array}{c}\text { Podstawa tworzenia za- } \\
\text { pasów }\end{array}$ & $\begin{array}{l}\text { Import netto ropy naftowej } \\
\text { i paliw ropopochodnych }\end{array}$ & Import \\
\hline
\end{tabular}

${ }^{a}$ Powiększone o szacunkową wartość zapasów należących do innych podmiotów działających na rynku oraz świadczących usługę biletowego przechowywania zapasów obowiązkowych (np. OLPP czy Apexim AB) (raporty roczne PKN Orlen i GK Lotos).

${ }^{\mathrm{b}} \mathrm{Na}$ podstawie raportu rocznego GK PGNiG.

${ }^{\mathrm{c}}$ Według standardów UE.

${ }^{\mathrm{d}}$ Według standardów Międzynarodowej Agencji Energii.

${ }^{\mathrm{e}}$ Ustawa o zapasach obowiązkowych (Ustawa z dnia 16 lutego 2007 r. o zapasach... 2007).

${ }^{\mathrm{f}}$ Łączna przeliczeniowa pojemność na ropę naftową i paliwa.

${ }^{g}$ Obliczono według przepisów na koniec 2012 r. i przy uwzględnieniu pojemności magazynowych na koniec 2012 r.; wielkość jest daną sumaryczną pojemności na ropę naftową i paliwa ciekłe.

${ }^{\mathrm{h}}$ Obliczono według pojemności magazynowych na koniec 2012 r. i przy uwzględnieniu konsumpcji w 2012 r.; przyjęto, że wielkość benchmarkowa magazynów odpowiada zużyciu gazu ziemnego w okresie 90-dniowym.

${ }^{\mathrm{i}} \mathrm{W}$ przypadku rozbudowy zakłada się procesy inwestycyjne z wykorzystaniem już działającej infrastruktury.

Rzeczą znamienną jest, że zgodnie z zapisami dyrektywy Rady 2009/119/WE z dnia 14 września 2009 r. nakładającej na państwa członkowskie obowiązek utrzymywania minimalnych zapasów ropy naftowej lub produktów ropopochodnych państwo polskie nie musiało brać na siebie obowiązku odkupowania zapasów ropy naftowej i paliw (podobnie, jak nie ma obowiązku tworzenia zapasów obowiązkowych) od importerów i handlowców. Zdecydowało się jednak na taki krok, mimo że sektorem bardziej potrzebującym takiego rozwiązania był i jest sektor gazu ziemnego (por. tab. 5). Ponadto zmieniają się również funkcje podziemnych magazynów gazu. Obecnie służą one nie tylko do przechowywania 
paliwa stanowiącego strategiczną rezerwę na wypadek przerwania dostaw gazu oraz umożliwiają sezonowe równoważenie obciążeń w celu zaspokojenia szczytowego popytu i bilansowanie dobowe.

Odpowiadają one także za (Stopa et al. 2007):

- arbitraż cen gazu, czyli handlową optymalizację wahań cen gazu;

- ogólną optymalizację funkcjonowania całego systemu, w tym ułatwienia transakcji wymiennych gazu typu swap;

- podtrzymanie przesyłu dzięki niwelowaniu lokalnych ograniczeń przepustowości systemu lub krytycznych dopuszczalnych wielkości ciśnień.

\section{KONKLUZJE}

1. W przyszłości w wyniku implementacji przepisów UE do prawa polskiego wielkość obowiązkowych zapasów gazu ziemnego ulegnie obniżeniu, jednakże obowiązek utrzymania tempa ich udostępniania w przypadkach kryzysowych się nie zmieni.

2. W ciągu najbliższych 5-7 lat Polska nie powinna mieć problemów związanych z posiadaniem odpowiednich jak na swoje potrzeby pojemności magazynowych.

3. Obecnie istnieje konieczność rozpoczęcia inwestycji w nowe podziemne magazyny gazu ziemnego w kawernach solnych; w przyszłości magazyny te umożliwią przechowywanie zapasów obowiązkowych, ale także obsługę rozwijającego się polskiego rynku gazu ziemnego.

4. Działania władz polskich powinny zmierzać do wprowadzenia państwowego, składkowego systemu magazynowania zapasów obowiązkowych, który byłby finansowany przez wszystkich sprzedających gaz ziemny na terenie RP.

\section{LITERATURA}

Dyrektywa Parlamentu Europejskiego i Rady 2010/75/EU z dnia 24 listopada 2010 r. w sprawie emisji przemysłowych (zintegrowane zapobieganie zanieczyszczeniom $i$ ich kontrola) (wersja przeksztatcona). Dziennik Urzędowy Unii Europejskiej L 334/17 [Directive on industrial emissions 2010/75/EU - IED].

Energetyka cieplna w liczbach - 2011 [raport Prezesa URE], 2012. Urząd Regulacji Energetyki, Warszawa.

Informacja przedstawiciela Ministerstwa Gospodarki podczas obrad sejmowej podkomisji nadzwyczajnej do rozpatrzenia poselskiego projektu ustawy o zmianie ustawy Prawo energetyczne oraz niektórych innych ustaw (druk nr 946) w dniu 21.02.2013 r., [online:] http://www.sejm.gov.pl/Sejm7.nsf/transmisje_arch.xsp?rok=2013\&month=02\#22E606 7F3C54B2F6C1257B17004C1DCC [dostęp: grudzień 2013]. 
Informacja przedstawicieli PGNiG SA na posiedzeniu sejmowej Komisji Skarbu Państwa w dniu 04.04.2013 r., [online:] http://www.sejm.gov.pl/Sejm7.nsf/biuletyn.xsp?skrn$\mathrm{r}=$ SUP-62 [dostęp: grudzień 2013].

Kopczyński O., 2012. Energetyka cieplna w kontekście wymagań ochrony środowiska. XII Ogólnopolski Kongres Energetyczno-Ciepłowniczy „PowerPol”, Kazimierz Dolny, 7-8 marca 2012 r., [online:] http://www.youtube.com/watch?v=Ol6Qjz6zoiY [dostęp: grudzień 2013].

Projekt ustawy Prawo gazowe z dnia 21 grudnia 2011 r., [online:] http://www.cire.pl/pokazpdf-\%252Fpliki\%252F6\%252Fprawo_gazowe_projekt_19256.pdf [dostęp: grudzień 2013].

Raporty roczne Grupy Lotos SA za 2011 r., [online:] http://inwestor.lotos.pl/193/raporty_i_ dane/raporty_roczne [dostęp: grudzień 2013].

Raport roczny GK PGNiG SA za 2011 r., [online:] http://www.pgnig.pl/pgnig/ri/838/ rr2011/?s,main,language=PL [dostęp: grudzień 2013].

Rapotr roczny GK PKN Orlen SA za 2011 r., [online:] http://www.orlen.pl/PL/RelacjeInwestorskie/Raportyroczne/Documents/Raport_roczny_2011.pdf [dostęp: grudzień 2013].

Rozporzadzenie Parlamentu Europejskiego i Rady (UE) nr 994/2010 z dnia 20 października 2010 r. w sprawie środków zapewniajacych bezpieczeństwo dostaw gazu ziemnego i uchylenia dyrektywy Rady 2004/67/WE. Dziennik Urzędowy Unii Europejskiej L 295/1.

Stopa J., Rychlicki S. \& Kossowski P., 2007. Prognoza ekonomiki podziemnego magazynowania gazu w Polsce. Wiertnictwo Nafta i Gaz, 24, 1, 487-493.

Strategie GK PGNiG SA - strategia z 2008 roku [Strategia Grupy Kapitałowej PGNiG w perspektywie roku 2015: http://www.bankier.pl/wiadomosc/PGNIG-Strategia-GrupyKapitalowej-PGNiG-w-perspektywie-roku-2015-1862185.html, dostęp: grudzień 2013] oraz strategia z 2012 roku [Krótkoterminowa strategia budowania wartości GK PGNiG do 2014 roku, http://www.pgnig.pl/pgnig/216/14600/43445, dostęp: grudzień 2013].

Ustawa z dnia 16 lutego 2007 r. o zapasach ropy naftowej, produktów naftowych i gazu ziemnego oraz zasadach postępowania $w$ sytuacjach zagrożenia bezpieczeństwa paliwowego państwa i zakłóceń na rynku naftowym. Dz. U. 2007, nr 52, poz. 343. 